\title{
REGULATION OF MERGERS AND ACQUISITIONS IN TERMS OF THE SOUTH AFRICAN COMPANIES ACT 71 OF 2008: AN OVERVIEW
}

\author{
MADIMETJA PHAKENG, \\ The Cape Bar - Society of Advocates (Cape Town, South Africa)
}

https://doi.org/10.21684/2412-2343-2020-7-1- 91-118

The Companies Act 71 of 2008 (the 2008 Act) replaced the Companies Act No. 61 of 1973, effective 1 May 2011. The 2008 Act was aimed at keeping pace with developments in company law internationally. It is not intended to entirely replace the well-established principles and has largely retained the pre-existing South African company law. The mergers and acquisitions provisions are aimed at creating transparent, efficient, and simple procedures. Different types of mergers and acquisitions are clearly defined as "affected transactions" or "offers" in section 117. Section 118 provides for companies to which the provisions apply. The reasons for regulating these transactions and powers of the regulator - The Takeover Regulation Panel, have been reviewed, clarified, and improved. The previous section on disposal of all or greater part of assets or undertaking of a company has been re-written. The 2008 Act further introduces a new type of affected transaction in section 113, in the form of a "merger" or an "amalgamation." The 2008 Act has retained the scheme of arrangement in section 114, but has changed its format by removing compulsory court application and approval. The courts get involved under certain prescribed circumstances. The 2008 Act has enhanced shareholder protection for fundamental transactions in the form of section 164 -Appraisal Rights and section 115, dealing with shareholder approval of fundamental transactions. Some scholars and practitioners have criticised certain provisions. However, in general, the provisions have received favourable commentary. They regarded as progressive and comparable with others internationally.

Keywords: Companies Act 71 of 2008; affected transactions; offers; mergers; acquisitions; Takeover Panel Regulation; provisions, regulation; South Africa. 
Recommended citation: Madimetja Phakeng, Regulation of Mergers and Acquisitions in Terms of the South African Companies Act 71 of 2008: An Overview, 7(1) BRICS Law Journal 91-118 (2020).

\section{Table of Contents}

\section{Introduction}

1. The Regulatory Bodies Responsible to Regulate Mergers and Acquisitions

2. A Brief Overview of the Powers of the Takeover Regulation Panel

3. A Brief Overview of the Reasons for Regulating Mergers and Acquisitions

4. Companies That Are Subject to Mergers and Acquisitions Provisions

5. A Brief Overview of the Types of Mergers and Acquisitions Regulated

6. Specific Requirements for Fundamental Transactions

7. An Overview of Provisions Regulating the Conduct of Parties Involved in Mergers and Acquisitions

8. A Brief Overview of the Provisions for Enforcement and the Remedial Actions for Mergers and Acquisitions

9. A Brief Overview of Some of the Disclosure Regulations for Mergers and Acquisitions

Concluding Comments

\section{Introduction}

A number of years have passed since the South African merger and acquisitions (M\&As) provisions in terms of the Companies Act 71 of 2008 (the 2008 Act) became effective on 1 May 2011. The 2008 Act made comprehensive changes to the South African company law. The Act repealed the Companies Act No. 63 of 1973 (the 1973 Act). Prior to promulgating the 2008 Act, the South African Department of Trade and Industry (DTI), published a policy document titled "South African Company Law for the $21^{\text {st }}$ Century: Guidelines for Corporate Law Reform" (the DTI Guidelines). The 2008 Act is in line with the document and among others, seeks to make company law simple, flexible, transparent, predictable, and efficient. According to the Guidelines

...should attempt, where practically possible, to balance the competing interests of economic actors and of society at large.'

South African Department of Trade and Industry, South African Company Law for the $21^{\text {st }}$ Century: Guidelines for Corporate Law Reform (May 2004), at 9 (Feb. 2, 2020), available at https://www.gov.za/ sites/default/files/gcis_document/201409/26493gen1183a.pdf. 
The DTI Guidelines indicated that the mergers and acquisitions provisions published under the $1973 \mathrm{Act}$ are aligned with international practices. ${ }^{2}$ But, the Guidelines also indicated that there is a need to review the enforcement powers that existed under the 1973 Act to ensure compliance. ${ }^{3}$ The guideline also indicated that the rewrite is not aimed at "unreasonably jettisoning the body of jurisprudence built up over more than a century." But the aim was to appropriately align company law to the legal, economic and social context of South Africa as a constitutional democracy and open economy. ${ }^{5}$

In its preamble, among others, the 2008 Act confirms the approach of the Guidelines by indicating that it seeks "to provide for equitable and efficient amalgamations, mergers and acquisitions of companies." ${ }^{11}$ The aim of the DTI Guidelines is further carried through in section 7 indicating the intention of the legislature in enacting the 2008 Act. Among others, it provides that the purpose of the Act is to promote compliance with the Bill of Rights, as enshrined in the South African company law in the application of company law and to promote the development of the South African economy. A well-known scholar and legal practitioner, M.M. Katz, who also indicates that the 2008 Act is "a ground-breaking legislation which will have such an important impact on the commercial environment in South Africa," further confirms this approached in his article.' He further point out that

The legislation is world-class and places South Africa at the forefront of corporate law reform. ${ }^{8}$

Another scholar indicates that

The comparative analysis addresses protection of stakeholder rights; board duties, governance, and independence; appointment and removal of directors; director and management compensation; board supervision of management; and share-holder rights. Our analysis confirms that, in line with tested standards in other major economies and current international trends in corporate governance, the Companies Act sets out a modern, enabling model of regulation. In providing for flexibility and simplicity of company formation,

2 DTI Guidelines, at 42.

3 Id. at 3.

4 Id. at 8.

5 Id.

6 Preamble to the Companies Act 71 of 2008 as amended.

7 Michael M. Katz, Governance Under the Companies Act 71 of 2008: Flexibility Is the Keyword, Acta Juridica 248, 262 (2010) (dealing with Conclusion).

8 Id. 
transparency of governance, and effective exercise of shareholder rights, the Act creates a secure environment for entrepreneurship and investment. At the same time, it establishes standards of corporate responsibility distinctly appropriate to South Africa. ${ }^{9}$

Regulation of mergers and acquisitions is "a complex and controversial topic among policymakers, managers, investors and academics alike."10 However, it also indicated that

A well-regulated takeover market can create wealth for society by improving the allocation of productive resources. On the other hand, theoretical and empirical research agrees that an unregulated market for corporate control increases the cost of capital for firms by allowing inefficient transfers of control and thus fails to establish allocate efficiency."

The 2008 Act borrowed extensively from corporate laws of other jurisdictions.' ${ }^{12}$ It has incorporated numerous elements of Australian, American and mainly United Kingdom laws, derived from the United Kingdom City Code on Takeovers and Mergers. ${ }^{13} \mathrm{~A}$ quick overview of research articles suggests that there is generally dearth of research on regulation of mergers and acquisitions under the South African company laws. This article seeks to add to existing body of knowledge in this area of corporate law. It provides an overview of the regulation of the different types of mergers and acquisitions under the 2008 Act. The discussions include a brief overview of the provisions of the 1973 Act and those of the 2008 Act in respect of mergers and acquisitions. In this article, the terms "mergers" and "acquisitions," or in short, "M\&As" - the practitioners' vernacular language, ${ }^{14}$ are used for convenience interchangeably with the "affected transactions" ${ }^{\prime 15}$ defined in the 2008 Act.

9 John F. Olson, South Africa Moves to a Global Model of Corporate Governance but with Important National Variations, Acta Juridica 219, 219 (2010).

10 Ying Wang \& Henry Lahr, Takeover Regulation to Protect Shareholders: Wealth Creation or Wealth Destruction? (January 2015), at 2 (Feb. 2, 2020), available at https://pdfs.semanticscholar.org/f19f/93 d3f97bb7581cb688efbf577820fba63d21.pdf.

11 Id.

12 Piet Delport, Companies Act 71 of 2008 and the "Turquand" Rule, 74 Journal of Contemporary RomanDutch Law 132 (2011) (Feb. 2, 2020), available at https://ssrn.com/abstract=2016801.

13 Nigel Boardman, A Critical Analysis of the New South African Takeover Laws as Proposed Under the Companies Act 71 of 2008, Acta Juridica 306, 336 (2010).

14 See Ezra Davids et al., A Microscopic Analysis of the New Merger and Amalgamation Provision in the Companies Act 71 of 2008, Acta Juridica 338 (2010).

15 Section 117(1)(c) of the Act defines these transactions as follows:

"'affected transaction' means- 


\section{The Regulatory Bodies Responsible to Regulate Mergers and Acquisitions}

The 2008 Act creates, empowers and clarifies the role of the Takeover Regulation Panel (TRP), ${ }^{16}$ a new body that replaced the Securities Regulation Panel (SRP). ${ }^{17}$ The TRP performs the same functions as that of the SRP that existed under the 1973 Act. The powers and functions of the TRP have been strengthened, as will be indicated later in the article. Members of the TRP may not be more than 15 persons. Members of the TRP consists of the Competition Commissioner or a person designated by him or her, the Commissioner of the Companies Commission or a person designated by him or her, and 3 persons are designated by each exchange. The Minister of the Department of Trade and Industry (the Minister) appoints additional members based on their experience and knowledge of acquisitions and securities regulation. ${ }^{18}$ The term of office of the Members is five years in the case of members appointed by the Minister, ${ }^{19}$ while those appointed by the exchange, or in the case of the Companies Commissioner or their nominees and the Competition Commissioner or their nominees, hold office for 5 years, provided that they are still in the service of those institutions. ${ }^{20}$ The TRP may also co-opt additional members for a specific purpose and for a limited period. ${ }^{21}$ The Minister may designate a chairperson and deputy chairpersons of the TRP from among members of the TRP. Its Executive Director or the deputy Executive Director and other employees undertake the daily operations of the TRP. ${ }^{22}$ The structure of the TRP and the process of appointment of TRP members differs from those that existed under the 1973 Act.

(i) a transaction or series of transactions amounting to the disposal of all or the greater part of the assets or undertaking of a regulated company, as contemplated in section 112, subject to section 118(3);

(ii) an amalgamation or merger, as contemplated in section 113, if it involves at least one regulated company, subject to section 118(3);

(iii) a scheme of arrangement between a regulated company and its shareholders, as contemplated in section 114, subject to section 118(3);

(iv) the acquisition of, or announced intention to acquire, a beneficial interest in any voting securities of a regulated company to the extent and in the circumstances contemplated in section 122(1);

(v) the announced intention to acquire a beneficial interest in the remaining voting securities of a regulated company not already held by a person or persons acting in concert;

(vi) a mandatory offer contemplated in section 123; or

(vii) compulsory acquisition contemplated in section $124 . "$

16 Sections 196 and 197 of the 2008 Act.

17 The Securities Regulation Panel was created by the section 440B of the Companies Act of 1973.

18 Section 197(1)(a)-(d) of the 2008 Act.

19 Id. sec. 197(4).

20 Id.

21 Id. sec. 197(2).

22 Id. sec. 200. 
Under the 1973 Act, a number of institutions and organisations were entitled to nominate members of the SRP, who were then appointed to the SRP by the Minister. ${ }^{23}$ In terms of the 2008 Act, the Minister decides who is appointed as a member of the TRP, except in the case of members who are appointed in their official capacity such as members appointed by the JSE Limited or other exchanges. ${ }^{24}$

Section 202(1) of the 2008 Act also creates a new body known, as the Takeover Special Committee is a committee of the TRP. The Takeover Special Committee (TSC) members consist of at least three persons. ${ }^{25}$ The TSC is tasked under the Act to hear and decide referrals directly made to it by the Executive Director, deputy Executive Director or the TRP. The TSC may also review compliance notices issued by the Executive Director or deputy Executive Director of the TRP. ${ }^{26}$ The members of the Takeover Special Committee are designated from time to time by the TRP from those members of the TRP who have been appointed by the Minister in terms of section 197(1)(d). The functions of the TSC are similar to those of the Appeal Committee of the SRP created under the SRP Code and the 1973 Act but with some difference. ${ }^{27}$ The difference is that under the 1973 Act, the Appeal Committee was created in the SRP Code a subordinate legislation being a regulation promulgated in terms of the $1973 \mathrm{Act}$, whereas the TSC is created in the Act. $^{28}$ The number of Appeal Committee in the SRP Code consisted of 5 members, and it may have included any member of the SRP, irrespective of the body or organisations that nominated the person..$^{29}$ However, in the case of the TSC only members appointed by the Minister in terms of section 197(1)(d) of the Act may be members of the TSC. ${ }^{30}$ Another difference is that section 202(2) of the Act requires that the chairperson of the TSC be either an Attorney or an Advocate, whether practising or not. The SRP Code did not have such a requirement.

\section{A Brief Overview of the Powers of the Takeover Regulation Panel}

Section 201 of the Act sets four powers of the TRP." The powers are to: (a) regulate affected transactions and offers to the extent provided for, and in accordance with, Parts B and C of Chapter 5 and the Takeover Regulations; (b) investigate complaints

\footnotetext{
23 Section $440 B(3)$ of the 1973 Act.

24 Section 197(1)(d) of the 2008 Act.

25 Id. sec. 202(2).

26 Id. sec. 202(3).

27 See SRP Code in section 2(d).

28 Section $440 C$ of the 1973 Act and the SRP Code in section 2(d).

29 See SRP Code in section A2(d).

30 Section 202(2)(b) of the 2008 Act.

$31 \quad$ Id. sec. 201.
} 
with respect to affected transactions and offers in accordance with Part D of Chapter 7; (c) apply for a court order to wind up a company, in the manner contemplated in section 81(1)(f); and (d) consult with the Minister in respect of additions, deletions or amendments to the Takeover Regulations. The powers to apply for winding up a company in terms section 81 (f) where the officers have committed fraud, an illegality or have failed to comply is new and did not exist under the 1973 Act, while the other three existed in one form or another. ${ }^{32}$ The offending act must have been committed in the previous five years and the officers must have received an administrative fine or a conviction for the same conduct. It appears that this section is aimed at repeat offenders. The TRP has no authority to regulate affected transactions relating to fundamental transactions entered into by a company that is subject to a business rescue plan in terms of Chapter $6 .^{33}$

\section{A Brief Overview of the Reasons for Regulating Mergers and Acquisitions}

Section 119 sets out the reasons for regulating mergers and acquisitions. It provides:

119. Panel regulation of affected transactions

(1) The Panel must regulate any affected transaction or offer in accordance with this Part, Part C and the Takeover Regulations, but without regard to the commercial advantages or disadvantages of any transaction or proposed transaction, in order to-

(a) ensure the integrity of the marketplace ${ }^{34}$ and fairness to the holders of the securities of regulated companies;

(b) ensure the provision of-

(i) necessary information to holders of securities of regulated companies, to the extent required to facilitate the making of fair and informed decisions; and

(ii) adequate time for regulated companies and holders of their securities to obtain and provide advice with respect to offers; and

(c) prevent actions by a regulated company designed to impede, frustrate, or defeat an offer, or the making of fair and informed decisions by the holders of that company's securities.

\footnotetext{
32 See Chapter XVA of the 1973 Act.

33 Section $118(3)$ of the 2008 Act.

34 See DTI Guidelines, at 43. The Guidelines state that mergers and takeovers must ensure integrity of the market and also protect the interests of other stakeholders.
} 
Section 119(1) encapsulates the general principles of regulation of M\&As that existed under the SRP Code. ${ }^{35}$ These principles have been reworded and subdivided into three subsections. ${ }^{36} \mathrm{~A}$ quick overview of those general principles and section 119(1) indicates that the section forms the cornerstone of regulating M\&As. The general principles originated from the United Kingdom Code on Takeovers and Mergers (the UK City Code) issued by the Panel on Takeover and Mergers in the United Kingdom. ${ }^{37}$

Section 119(1) also indicates that the TRP must not have regard to commercial advantages or disadvantages of mergers and acquisitions in its regulatory process. As if to emphasize this point, section 201(3) provides that the TRP must not express any view or opinion on commercial advantages or disadvantages on any transactions when exercising its powers and performing its functions. In this respect, the 2008 Act is similar to the 1973 Act, which provided for powers of the SRP. The SRP also, did not consider the advantages or disadvantages of mergers and acquisitions, when it regulated such transactions. ${ }^{38}$ The UK City Code has similar restrictions and the UK Panel does not consider the commercial advantages or disadvantages of M\&As. ${ }^{39}$ According to this approach, it is the affected shareholders who should consider the commercial advantages or disadvantages of mergers and acquisitions. ${ }^{40}$ The affected shareholders are in a better position to judge whether an affected transaction or offer has advantages or disadvantages based on their personal investment aims and decisions. Regulators are not able to judge or know the investment decisions of each individual shareholder, particularly where the shares of the company are widely held. Even in cases where the shareholding is not widely held, it is not appropriate for regulators to consider commercial advantages or disadvantages of M\&As.

\section{Companies That Are Subject to Mergers and Acquisitions Provisions}

Regulated companies that undertake an affected transaction or offer, must comply with the takeover provisions unless exempted by the TRP. ${ }^{41}$ The Act defines

35 See SRP Code in section C and General Principles of the Code.

36 Section 119(1)(a), (b) and (c) of the 2008 Act.

37 See SRP Code in section C, General Principles and also the introduction to the SRP Code.

38 Section $440 C(2)$ of the 1973 Act.

39 A Practitioner's Guide to the City Code on Takeovers and Mergers, 2006/2007 1 (M. Button (ed.), London: City \& Financial Publishing, 2006). See also Securities Regulation Code and the Rules of the Securities Regulation Panel (SRP Code), South African Government Gazette No. 12962, January 1991 in the introduction to the SRP Code.

40 See Button 2006, at 1.

41 Section 117 (i) of the 2008 Act read with section 118 of the 2008 of the Act. 
regulated companies as: for profit companies, that are public companies; state-owned companies unless exempted; and private companies, which had 10 percent or more of their issued securities transferred within a period of 24 months immediately prior to the date of a particular affected transaction, excluding transfers between or among related or inter-related persons, or a company whose Memorandum of Incorporation expressly provides that the company and its securities are subject to provisions of the Act in Part B, Part C of Chapter 5, and the Takeover Regulations in Chapter 5 of the Companies Regulations. The 1973 Act had similar provisions relating to state owned companies and public companies. ${ }^{42}$ However, in respect of private companies, there is a significant difference between the 1973 Act and the 2008 Act. In terms of the 1973 Act and the SRP Code, private companies were subject to the M\&A provisions only where the private company had more than 10 beneficial shareholders, and the transaction value was more than $\mathrm{R} 5$ million. In addition, the provisions were contained only in the SRP Code, a regulation, whereas in terms of the 2008 Act, the provisions are both in the Act and the Companies Regulations. ${ }^{43}$

There is criticism of the manner, which the takeover provisions apply to private companies as provided in section 118 of the Act. The provision makes the takeover provisions applicable to a wide range of private companies even where there is no risk of unfair or unequal treatment to shareholders and therefore no need to protect shareholders under such circumstances. The section unnecessarily burdens small private companies with compliance and associated costs. Unless exempted by the TRP, small companies will be forced to comply with M\&A provisions. Exemptions require that companies must apply to the TRP and therefore, this results in addition of bureaucratic compliance and resultant costs to small businesses. It is indicated that the measurement of 10 percent transfer of shares in the regulated company in terms of section 118 is regarded as irrelevant. ${ }^{44}$ The logical and commercial measure should be value and the number of shareholders to determine the type of companies that should be subject to the takeover provisions..$^{45} \mathrm{It}$ is submitted that this requirement also appears to be contrary to one of the stated objectives of the DTI Guidelines aimed at reducing compliance costs. ${ }^{46} \mathrm{It}$ is further indicated that the benefits of transparency as weighed against the costs of compliance are disproportionate and at worst unnecessary. ${ }^{47}$ The threshold set in the SRP Code should have been retained

42 Chapter XVA of the 1973 Act read with section A3 of the SRP Code.

43 Section A3 of the SRP Code.

44 See Harvey E. Wainer, The New Companies Act: Peculiarities and Anomalies, 126(4) South African Law Journal 806, 825 (2009).

45 See 1 d.

46 See DTI Guidelines, at 43.

47 Boardman 2010, at 318. 
but with a higher threshold in number of shareholders and the value of transactions. This would allow oversight by regulators and also ensure that any possible prejudice to minority shareholders in private companies is limited. Such a threshold will also avoid the unintended consequences of adding a burden of compliance, and costs to all small private companies. It appears that the relevant authorities have considered the criticism made against this requirement. The Minister released the Companies Amendment Bill (the Bill), 2018 for public comments on 21 September 2018. The Bill proposes a number of amendments. It includes the much-criticised section 118(1)(c) (i) which creates the obligation for private companies to comply with the takeover provisions. It is proposed that private companies will become regulated companies if the private company is required by the Act or the regulations to have its annual financial statements audited every year. ${ }^{48}$ If passed, the amendment will apply to those private companies that are also subject to the requirements of Chapter 3 of the Act, dealing with the extended accountability and transparency applicable to certain companies. The proposed amendment will ensure that only larger private companies are required to comply with the takeover provisions.

\section{A Brief Overview of the Types of Mergers and Acquisitions Regulated}

"Affected transactions" include both those transactions referred to as "fundamental transactions ${ }^{\prime \prime 49}$ and "offers." ${ }^{150}$ The heading in part A of Chapter 5 of the 2008 Act, sets out three fundamental transactions. The transactions have specific requirements, which will be discussed underneath. The 2008 Act does not specifically refer to the distinction between part A and Part B of Chapter 5. However, it is clear that it is possible that a company may enter into a fundamental transaction under Part A without triggering the authority of the TRP under Part B. This is so considering the wording of section 117, dealing with definitions applicable to Part B. Fundamental transactions are: firstly, the disposal of all or greater part of the assets or undertaking of a company in terms of section 112 of the Act. This section is substantially similar to section 228 of the 1973 Act. Section 112 includes a definition of what constitutes "all or the greater part of the assets or undertaking" being disposed. The 1973 Act did not have such a definition. ${ }^{51}$ The definition will assist practitioners and companies

48 See Companies Amendment Bill, 2018, South African Government Gazette No. 41913, 21 September 2018 (Feb. 2, 2020), available at http://www.cipc.co.za/files/7715/4149/0472/Companies_Amendment_ Bill_2018.pdf.

49 See Chapter 5, Part A headed "Approval of Fundamental Transactions" of the 2008 Act.

50 See section 117(1) definitions of "affected transactions" and "offers" of the 2008 Act.

51 Section 1 of the 2008 Act defines "All or the greater part of the assets or undertaking" as meaning more than 50 percent of the company's gross assets at fair market value, irrespective of its liabilities; or more than 50 percent of the company's value of its entire undertaking, at fair market value. 
in interpretation of the section rather than leaving the interpretation to the courts. Another difference is that section 112 clarifies that the disposal of the assets or undertaking must be done at fair value. Despite criticism due to lack of guidance, it nevertheless a useful starting point.

Secondly, section 113 dealing with amalgamations or merger transactions is another type of fundamental transaction. ${ }^{52}$ This is a new type of affected transactions that did not exist under the 1973 Act. The Act does not define the new terms individually but are defined jointly. ${ }^{53}$ This suggests that there is no distinction between the two..$^{54}$ Davids, Norwitz and Yuill ${ }^{55}$ in their article deal with these transactions in details and convincingly set out the merits of introduction of these types of transactions. It has been suggested that the new provision will facilitate the creation of business combinations..$^{56}$ According to Cassim ${ }^{57}$ in a comprehensive analysis of the section, the introduction of the amalgamation and merger provisions is a significant liberalisation of policy by the legislature. Cassim and Yeats ${ }^{58}$ indicate that the merger and amalgamation provision is one of the leading reforms introduced by the 2008 Act. A statutory merger in the true sense is a new invention under the 2008 Act. $^{59}$ The procedure to complete a merger or an amalgamation in terms of the Act is not a complicated process. It requires completion of a number of clearly set out steps. These include an agreement by the merging or amalgamating companies, voting by shareholders of the relevant companies based on full disclosures. The rights of the shareholders must be set out in the disclosure document including, and dissenting shareholder appraisal rights to have their shares bought at "fair value" in terms of section 164 of the Act. The courts play a limited role based on

52 Section 1 of the 2008 Act defines amalgamations or mergers as meaning a transaction, or series of transactions, pursuant to an agreement between two or more companies, resulting in-

(a) the formation of one or more new companies, which together hold all of the assets and liabilities that were held by any of the amalgamating or merging companies immediately before the implementation of the agreement, and the dissolution of each of the amalgamating or merging companies; or

(b) the survival of at least one of the amalgamating or merging companies, with or without the formation of one or more new companies, and the vesting in the surviving company or companies, together with such new company or companies, of all of the assets and liabilities that were held by any of the amalgamating or merging companies immediately before the implementation of the agreement.

Definition in section 1 of the 2008 Act. See also Davids et al. 2010, at 341.

54 Id.

55 See in general Davids et al. 2010 and the discussions thereunder.

56 Id. and the discussions thereunder.

57 Maleka F. Cassim, The Introduction of the Statutory Merger in South African Corporate Law: Majority Rule Offset by the Appraisal Right (Part 1), 20 South African Mercantile Law Journal 1, 1 (2008).

58 Maleka F. Cassim \& Jacqueline Yeats, Fundamental Transactions, Takeovers and Offers in Contemporary Company Law 675 (F.H. Cassim et al. (eds.), $2^{\text {nd }}$ ed., Claremont: Juta, 2012).

59 See Id. at 676. 
specified circumstances.$^{60}$ The legislature is trying to balance the interests of the shareholders and economic growth by introducing the statutory merger to facilitate such transactions. ${ }^{61}$

The third affected transaction is the scheme of arrangement in terms of section 114 of the Act. The 2008 Act introduced significant changes to the procedure for implementing a scheme of arrangement. The new process is fundamentally different to the process under the 1973 Act. Under the 1973 Act, court involvement in a scheme of arrangement was a prerequisite. At least two court approvals were required before the companies undertaking a scheme of arrangement could implement the affected transaction. ${ }^{62}$ Another difference is that section 114 of the 2008 Act specifically provides a number of transactions that can be implemented using a scheme of arrangement as opposed to the section 113 of the 1973 Act. The transactions listed include: division, consolidation, expropriation, exchange, and repurchase of securities. The legislature intended to make it clear that schemes of arrangement can be applied to different types company structure reorganisations and it is not limited to any type of transaction. ${ }^{63}$ Similar to mergers or amalgamations, the role of the courts is limited to specified circumstances. ${ }^{64}$

The acquisition or intention to acquire beneficial voting securities in terms of section 122 is the fourth type of affected transaction. However, the inclusion of these transactions as affected transactions has not been generally accepted and has attracted numerous criticisms. A close consideration of the section shows a number of problems created by classifying the section as an affected transaction. The requirement under the definitions in section 117(1) is that acquisitions of, or announced intentions to acquire, beneficial interest in any voting securities of a regulated company amounting to 5 percent or any whole multiple of 5 percent of the securities of that class in terms of section 122 is an affected transaction. An analytical review of the section shows that such acquisitions require disclosure to companies and their shareholders. Therefore, it is inappropriate to classify such disclosures as affected transactions. Regarding these acquisitions as affected transactions is problematic, as they do not fit within clear categories of "affected transactions" or "offers" as defined in the Act, despite being defined as such. The legislature should have indicated that section 122 is a disclosure section and should not have formed part of affected transactions. However, the requirements of the section to disclose share dealings are in line with similar requirements in other countries. In those countries, such disclosures are reported and disclosed

\footnotetext{
60 Cassim \& Yeats 2012, at 677.

61 Cassim, The Introduction of the Statutory Merger in South African Corporate Law (Part 1), at 1.

62 See section 113 of the 1973 Act.

63 See also Cassim \& Yeats 2012, at 726.

64 Id. at 729. See also Boardman 2010, at 315.
} 
separately and are not regulated as a category of "affected transactions" or "offers." The disclosure of such share dealings, assist management of companies and other shareholders to see if any shareholder is building up a stake which may be used later to implement a takeover offer. ${ }^{66}$ According to some scholars, the inclusion of the disclosure requirements as an affected transaction can be interpreted to mean these transactions are "partial offers" or are "offers," as defined in the Act. ${ }^{67}$ Such an interpretation may have unintended consequences. For example, an interpretation that an acquisition of 5 percent of the shares is an affected transaction in the form of a partial offer, may be interpreted that having acquired a portion of the shares, the acquirer is obliged to make a partial offer to other shareholders to acquire 5 percent of their shares to ensure equality of treatment and fairness to other shareholders. ${ }^{68}$ Such an approach could lead to absurdities and is also that unworkable. ${ }^{69}$

The announced intention to acquire a beneficial interest in the remaining voting securities of a regulated company not already held by a person or persons acting in concert is the fifth affected transaction. This requirement is similar to that found in the 1973 Act. $^{70}$ This type of affected transaction makes sense it allows persons who wish to acquire the entire issued share capital of a regulated company to do so within a regulated and controlled environment. This promotes disclosures and protection of shareholders.

The mandatory offer in section 123 of the Act is the sixth "affected transaction." This requirement is triggered by the acquisition of 35 percent or more of the voting securities of a regulated company under the circumstances specified in section 123 of the Act. The requirements for triggering the mandatory offer obligation are similar to those applied by the UK Panel in terms of the City Code, ${ }^{71}$ although there are a number of differences. One of the differences is that the mandatory offer requirements of the UK City Code in Rule 9 is triggered at a threshold of acquisition of 30 percent or more of the voting rights compared to the 35 percent applicable in terms of the 2008 Act. $^{72}$

65 In the United Kingdom, such disclosures are required both during an M\&A transaction and even when there is not such a transaction. It has been submitted by Nigel Boardman that the United Kingdom disclosure requirements are much harsher. Further, in the same discussions, according to Boardman, Australian Takeover Panel may also regard failure to disclose in serious light.

Paul L. Davies, Gower's Principles of Modern Company Law 773 ( $6^{\text {th }}$ ed., London: Sweet \& Maxwell, 1997).

See section 125 of the 2008 Act. This section deals with partial offers and comparable offer. It states that parties making such an offer must acquire on pro-rata basis from each shareholder.

See Boardman 2010, at 329.

70 See Chapter XVA of the 1973 Act.

71 See rule 9 of the United Kingdom City Code 2016.

72 See rule 9 of the United Kingdom City Code 2016, and also the definitions in Chapter XVA of the 1973 Act and rule 8.1 of the SRP Code. 
The mandatory offer requirements in section 123 of the 2008 Act, was previously in rule 8.1 of the SRP Code, and not in the 1973 Act. $^{73}$

A compulsory acquisition of the remaining securities of a regulated company in terms of section 124 is defined as the seventh affected transaction. The transactions are commonly referred to in M\&A parlance as "the squeeze out." The legislature in the heading to section 124 of the Act has also adopted this terminology. A "squeeze out" transaction may be implemented where the acquirer has managed to acquire 90 percent or more of the shares of the regulated company that were the subject of the offer. In terms of the section, the acquirer is entitled to acquire the shares of any shareholder who did not accept the offer. The terms and conditions of the squeeze out must be the same as those of the initial offer. Equality of treatment between the shareholders who accepted the earlier offer and those who are subjected to the squeeze out provision is required. Section $440 \mathrm{~K}$ of the 1973 Act had similar requirements.

Section 48(8)(b), which is late addition to the Act in terms of the Companies Amendment Act, 2011 appears to add another "affected transaction" though not clearly. This is because section 48(8)(b) requires regulated companies that undertakes share repurchases to comply with the requirements of section 114 and 115 of the Act. Although section 48(8)(b) does not specifically refer to scheme of arrangement, section 114 is labelled "proposals for schemes of arrangement." Therefore, it argued that a section $48(8)$ (b) share repurchase must be undertaken in terms of a scheme of arrangement and it becomes an affected transaction. Section 115 in turn deals with procedural requirements to approve "fundamental transactions." A contrary assertion is that the section merely requires parties to make disclosures required by section 114 , and must then comply with procedural requirements of section $115 .{ }^{74}$ On this approach, a section 48(8)(b) share repurchase would not qualify as an affected transaction. According to some scholars and practitioners' section 48(8)(b) does not require share re-purchases to be implemented using a scheme of arrangement. Based on this view regulated companies may elect to use a scheme of arrangement to effect a re-purchase and where this is done, the transaction will amount to an affected transaction as defined in the Act. $^{75}$ The section has been criticised as unclear and its exact meaning even less clear. ${ }^{76}$ Further is argued that the subsection create some uncertainties. ${ }^{77}$ It appears that the criticism on this section has been taken to heart by the relevant authorities. The Companies Amendment Bill proposes changes to this section. ${ }^{78}$

73 See the definitions in Chapter XVA of the 1973 Act and rule 8.1 of the SRP Code.

74 See Johan Latsky, The Fundamental Transactions Under the Companies Act: A Report Back From Practice After the First Few Years, 25(2) Stellenbosch Law Review 361, 382 (2014).

75 See section 117 of the 2008 Act.

76 Piet Delport \& Quintus Vorster, Henochsberg on the Companies Act 71 of 2008. Vol. 1203 (Durban: LexisNexis, 2011).

77 Id.

78 See Companies Amendment Bill, 2018, supra note 48. 


\section{Specific Requirements for Fundamental Transactions}

Affected transactions in the form of disposal of all or the greater part of the assets or undertaking of a regulated company in terms of section $112,{ }_{1}^{79}$ proposals for an amalgamation or a merger of regulated companies in terms of section 113 and schemes of arrangement involving a regulated company in terms of section 114 of the Act are referred to as "fundamental transactions" in terms of the Act. ${ }^{80}$ The Act does not define the term "fundamental transaction." ${ }^{11}$ The three types of transactions referred to above clearly contemplate substantial changes to the corporate substructure or essence of the business of the regulated company implementing such a transaction. Perhaps that this is the reason why the legislature did not define the term, "fundamental transaction." Any company that implement any of the listed transactions will result in a completely changed company.

Section 115 of the Act set out shareholder approval requirements that must be met before a fundamental transaction is implemented. Among others, these include disclosures certain disclosures, affording shareholders appraisal rights and shareholder approval before the transaction may be implemented. ${ }^{82}$ However, if shareholders holding 15 percent of the votes and a meeting convened to vote on a fundamental transaction voted against it, court approval must be obtained before proceeding with the transaction. A company may also decide not to proceed with the transaction. ${ }^{83}$ The 2008 Act also changed procedural requirements in respect of schemes of arrangements. The involvement of the court as a prerequisite for the scheme has been removed, and the requirement that a court must convene a scheme meeting of shareholders, followed by the court sanctioning the scheme, as was required in terms of section 311 of the 1973 Act has been abolished. In terms of section 114 of the Act, only shareholder approval will be required and court involvement will only apply in certain circumstances ${ }^{84} \mathrm{It}$ is no longer mandatory as it was in terms of the 1973 Act. However, parties undertaking a scheme of arrangement must ensure compliance with a number of procedures including that an independent expert provides a fair and reasonable report to the shareholders. ${ }^{85}$

79 Section 1 of the 2008 Act defines "All or the greater part of the assets or undertaking" as meaning more than 50 percent of the company's gross assets at fair market value, irrespective of its liabilities; or more than 50 percent of the company's value of its entire undertaking, at fair market value.

80

81

82

83

84 have been met, such as where 15 percent of holders voted against the relevant resolution and sought court approval, or where the company applies to court for such approval.

85

See in Chapter 5 of the 2008 Act.

Cassim \& Yeats 2012, at 674.

Section 115(2) of the 2008 Act.

Id. sec. 115(4)(b).

Section 114(2) of the 2008 Act read with regulation 90, of the Companies Regulations 2011. 
The company is also required to comply with other requirements such as shareholder approval in terms of section 115 of the Act. In addition, parties are obliged to inform shareholders of the provisions of section 115 and also of their entitlements to exercise appraisal rights in terms of section 164 . It is submitted that the legislature have succeeded introducing a simplified procedure for the schemes of arrangement by removing the requirements of automatic court involvement.

In one of the example confirming that the legislature did not simply seek to change the well-established principles of South African company law is indicated in the case of Ex parte Federale Nywerhede Bpk.$^{86}$ This case, created one of the principle that there is no reason to give a narrow or limited meaning to an arrangement. As indicated in that case, safeguards in the form of disclosures have been required; there is a statutory majority and, in addition, court intervention in certain circumstances. This is in line with the principles set out in Ex parte Federale Nywerhede Bpk ${ }_{r}^{87}$ which indicate that by enacting provisions dealing with schemes of arrangement, the legislature seeks to ensure that companies can obtain shareholder approval in an efficient manner. The removal of automatic court involvement does not mean that shareholders have been left unprotected, as a new protective measure has been introduced in the form of appraisal rights in section 164 of the Act, in addition to shareholder approval in terms of section 115. In addition, shareholders will still have the right to ask the court to intervene provided certain requirements are met. ${ }^{88}$ It appears that the legislature has achieved a balance of interests for the parties involved in this type of transactions by introducing simplicity while balancing that with additional protection for shareholders. ${ }^{89}$

In the case of an amalgamation or a merger certain formalities must also be completed and observed in terms of section 116 of the Act. According to the policy document of the DTI, this new type of affected transaction is aimed at introducing efficient M\&As..$^{90}$ Cassim ${ }^{91}$ indicates that the amalgamation or mergers in terms of this section is a modernised and progressive concept borrowed from the USA. It is submitted that such an introduction has been well received. It makes mergers and acquisition simple and efficient. It will also contribute to the facilitation of mergers and takeovers. ${ }^{92}$

${ }^{86}$ Ex parte Federale Nywerhede Bpk, 1975(1) S.A. 826 W 264.

87 Id.

88 Section 115 of the 2008 Act.

89 See Latsky 2014, at 362.

90 DTI Guidelines, at 43.

91 Cassim \& Yeats 2012, at 677.

92 Maleka F. Cassim, The Introduction of the Statutory Merger in South African Corporate Law: Majority Rule Offset by the Appraisal Right (Part 2), 20 South African Mercantile Law Journal 147, 174 (2008). 
All fundamental transactions are required to comply with certain requirements before they may be implemented. These requirements are similar but dependent on each type of M\&A. However, the overriding requirement appears to be that all fundamental transactions must ensure that shareholders are aware of the protections offered to them in terms of sections 115 and 164 of the Act; that shareholders will have an opportunity to go to go to court provided certain safeguards have been observed, such as a requirement that 15 percent of the shareholders must have voted against the resolution. This ensures that a certain minimum objection level of members of the company at the shareholders meeting have raised their objections. Presumably to ensure that frivolous objections are avoided. In addition, all fundamental transactions are required to comply with the requirement for obtaining an independent adviser to advise the shareholders about the value of the shares they are selling, and in the case of the assets or undertaking of the company, the independent expert should provide a valuation of the undertaking or the assets being disposed of. ${ }^{93} \mathrm{It}$ is notable that the Act specifically requires that the independent expert report must include a copy of sections 115 and 164 . Cassim and Yeats ${ }^{94}$ indicate that presumably, this is to remind shareholders of their rights in terms of the Act. These requirements are additional to other disclosure requirements in terms of the regulations. ${ }^{95}$ Cassim, ${ }^{96}$ discussing the statutory merger in terms of section 113, of the Act indicates that section 164-appraisal remedy originated in the USA. It functions as a check in cases where directors make bad business judgments. ${ }^{97}$ The appraisal remedy may also serve to strengthen the rights of shareholders, particularly where collateral or side-payments to certain shareholders shave been made. Side payments may have the effect of rendering shareholder approval ineffective as a protection where there has been inadequate disclosure. ${ }^{98}$ Appraisal rights are aimed at assisting shareholders to exist the company whose risks may have changed and therefore do not wish to stay invested in the company. Appraisal rights create a market for mergers, and serve as a check on opportunism by the directors and controlling shareholders. ${ }^{99}$ The appraisal remedy allows shareholders an opportunity to exit the investment for cash but not to defeat a merger or an acquisition. Cassim ${ }^{100}$

\footnotetext{
93 Section 114(2) of the 2008 Act read with regulation 90 of the Companies Regulations 2011.

94 Cassim \& Yeats 2012, at 730.

95 Regulations 102 and 106 of the Companies Regulations 2011 contain detailed disclosure requirements and the timelines within which steps must be undertaken. The assumption is that timely disclosures will assist shareholders in making informed decisions.

96 See Cassim, The Introduction of the Statutory Merger in South African Corporate Law (Part 2), at 157.

97 See ld. at 158.

98 Id.

99 Id.

100 Cassim, The Introduction of the Statutory Merger in South African Corporate Law (Part 1), at 19.
} 
points out that shareholders have no legal basis for preventing a merger, which has been approved by the requisite majority, save in certain prescribed circumstances.

The introduction of the appraisal right appears to have been welcomed by a number of commentators. ${ }^{101}$ However, while the appraisal right has generally been welcomed, they have also been criticised on a number of aspects. Cassim ${ }^{102}$ commenting on the right as contained in the then Companies Bill before the 2008 Act, notes that the efficacy of the right is to be questioned due to its procedural flaws. Appraisal right remedy has also been criticised as too complex, technical and rigid for shareholders. It is pointed out that it is associated with delays and prohibitive costs..$^{103}$ It is notable that the appraisal right as contained in the Companies Bill remained substantially the same as it is in section 164 of the Act. Therefore, the comments by Cassim $^{104}$ in the article published prior to the 2008 Act are still applicable. Davids, Norwitz and Yuill ${ }^{105}$ share the view expressed by Cassim ${ }^{106}$ that the appraisal remedy may be costly to shareholders. It is pointed out this may discourage small shareholders with limited funding to exercise this right. It must be noted this section is one of the longest sections with subsections running from subsection 1 to subsection 19. It is submitted that the section is complex and shareholders may find it difficult to exercise this right without requiring some expert advice. Cassim ${ }^{107}$ noted that the appraisal right as a remedy has not been very successful in those countries, which have introduced it. It is indicated that companies tend to be wary of the rights. It appears that South Africa practitioners have sought to avoid the application of this right. In practice it appears that companies have introduced certain terms and conditions in merger documents which presumably are aimed at protecting the interests of the bidder and avoid paying a higher price where shareholders exercise this right. These terms include a suspensive condition in the mergers agreement that should a certain percentage, commonly 5 percent, of shareholders exercise their appraisal rights, and follow to the procedure to finality, the bidder reserves the right to terminate the $M \& A$ transaction. ${ }^{108}$ In another transaction legal advisers were

101 See Cassim, The Introduction of the Statutory Merger in South African Corporate Law (Part 2) discussing how the appraisal remedy will be beneficial to shareholders and that it serves as check on possible abuse of powers by directors.

Id. at 176

See the general discussions under appraisal rights in Cassim, The Introduction of the Statutory Merger in South African Corporate Law (Part 2).

See also in Cassim \& Yeats 2012, at 730.

Davids et al. 2010, at 366.

See also in general Cassim \& Yeats 2012 discussing fundamental transactions and appraisal rights. Id. at 798 .

See Metorex Limited a circular to shareholder regarding a scheme of arrangement in terms of section 114(1)(c) of the Companies Act 2008 dated 17 June 2011. This is probably one of the first circulars issued in terms of the Companies Act 2008 which introduced this condition. 
quoted as indicating that the appraisal right remedy causes uncertainty hence the attempt to neutralise it. ${ }^{109}$ The debates on the legality or otherwise of these terms and conditions is beyond the scope of this review.

Davids, Norwitz and Yuill ${ }^{110}$ hold that balances need to be struck between protection minority shareholders and the facilitation of economically advantageous transactions. Prudent regulation and risk taking should co-exist. Minority shareholders should not be allowed to hold transactions against the will of majority. It has also been indicated that minority protection is essential to encourage investment and also to preserve market integrity. ${ }^{111}$ It will be interesting to see how the appraisal rights develop taking into consideration the observations and the criticism about the complexity of the procedure. Case law on the appraisal right is still developing. However, should the criticism be proven correct, then it may be necessary for the legislature simplify the appraisal rights procedure by an amendment to section 164 of the 2008 Act.

\section{An Overview of Provisions Regulating the Conduct of Parties Involved in Mergers and Acquisitions}

The 1973 Act did not specifically deal with the conduct of parties involved in mergers and acquisitions but such conduct was dealt with in the rules and regulations - the SRP Code. ${ }^{112}$ The 2008 Act, however, specifically deals with such conduct in a number of sections. As part of its mandate, the TRP must ensure that the conduct of parties adhere to the provisions of section 119(2), when it regulates M\&As. ${ }^{113}$ The aim of section 119(2) is to ensure that the objects of section 119(1) as set

109 See also Ann Crotty, CapeVin Offer Shows How to Neutralise Dissenters' Rights, IOL, 17 April 2012 (Feb. 2, 2020), available at https://www.iol.co.za/business-report/economy/capevin-offer-shows-how-toneutralise-dissenters-rights-1277283.

110 See Davids et al. 2010, at 338.

111 See Boardman 2010, at 311.

112 See the SRP Code published under the 1973 Act with comprehensive rules on acquisitions and mergers.

113 Section $119(2)$ of the 2008 Act provides that:

"subject to the provisions of subsection (6),
(a) that no person may enter into an affected transaction unless that person is ready, able and willing to implement that transaction;
(b) that all holders of-
(i) any particular class of voting securities of an offeree regulated company are afforded equivalent treatment; and
(ii) voting securities of an offeree regulated company are afforded equitable treatment, having regard to the circumstances;
(c) that no relevant information is withheld from the holders of relevant securities; and
(d) that all holders of relevant securities- 
out above, are promoted when the TRP regulates M\&As. The TRP may require certain disclosures; the filing of documents for approval; issue compliance certificates; receive complains; investigate and issue compliance notices in respect of M\&As when undertaking its mandate. ${ }^{114}$ Section 119(5) gives the TRP some powers to ensure compliance. In terms of the section, the TRP may prohibit and require any action by a person; or may order a person to divest of an acquired asset; or to account for any profits made. Section 121 also creates an obligation for parties entering into affected transactions to report such transactions, and such transactions must not be effected unless they have been approved by the TRP or have been exempted from approval by the TRP. ${ }^{115}$ It appears that some provisions in the Act have been taken from the old SRP Code. Some of the wordings are similar almost word for word to those of the SRP Code. ${ }^{116}$ The 2008 Act also creates prohibitions on actions that may frustrate or prevent merger or acquisition transactions, ${ }^{117}$ unless shareholder approval, and the written approval of the TRP are obtained in terms of section 126(1). Collateral or favourable benefits to some shareholders to the exclusions of others during merger or acquisition transactions are also prohibited in terms of section 127(1). Parties may not enter into new transactions for a minimum period following the ending of an earlier transaction in terms of section 127(5) of the 2008 Act. The regulations also provide detailed actions which directors are required to perform during a merger or takeover to ensure that the interests of shareholders are protected and are discussed below. ${ }^{118}$ These provisions are in line with the aim of the 2008 Act in respect of the M\&As including to ensure that: parties who undertake mergers and acquisitions do not mislead market participants; assists in promoting equality of treatment of shareholders, and that parties to such transactions do not give preference to some shareholders. Further, the provisions assists in ensuring that there is sufficient details about M\&As and that such information is provided timeously; they also seek to ensure that shareholders are denied a fair chance to consider the merits or demerits of an affected transaction or an offer. This could happen where there is insufficient information or where there are time constraints to consider the M\&A transaction. ${ }^{119}$ It is suggested that this is in line with the general rules of fairness and equity that requires that, in order to make informed decisions, shareholders need detailed information

(i) receive the same information from an offeror, potential offeror, or offeree regulated company during the course of an affected transaction, or when an affected transaction is contemplated; and (ii) are provided sufficient information, and permitted sufficient time, to enable them to reach a properly informed decision."

114 Section 119(4) of the 2008 Act.

115 Id. sec. 121(b).

116 Rule 19 of the SRP Code.

117 This provision is similar to Rule 19 of the SRP Code published under the 1973 Act.

118 See Chapter 5 of the Companies Regulations 2011 for the detailed regulations.

119 Section 119(1) and section 119(2) of the 2008 Act. 
that must be provided in good time. In this way, shareholders are able to consider the information and to seek independent advice should they choose to do so. The UK City Code has similar principles. ${ }^{120}$ These principles also form a foundation of merger and acquisitions provisions of a number of countries. ${ }^{121}$ The European Directive on Takeovers and Mergers has adopted similar principles, and it is indicated that the principles are modelled on the UK City Code. ${ }^{122}$

\section{A Brief Overview of the Provisions for Enforcement and the Remedial Actions for Mergers and Acquisitions}

In enforcing the $2008 \mathrm{Act}$, the court and the TRP must promote the spirit, purpose and objects"123 of the Act and must also interpret the provisions in a manner that promotes the purpose and objectives set out in the Act where a provision may have more than one meaning. According to the DTI Guidelines, the enforcement mechanism in the 2008 Act was intended to avoid litigation during mergers and acquisitions. ${ }^{124}$ The enforcement mechanisms are in Chapter 7 of the Act. They include: the TRP issuing a compliance notice to transgressors prior to approaching the courts, which is in line with the above intention. Unlike the 1973 Act, $^{125}$ the 2008 Act provides clearer measures for the TRP to enforce compliance with the mergers and acquisitions provisions. Section 440 L of the 1973 Act, prohibited any person from concluding or proposing an affected transaction unless exempted in accordance with the Act. Section 121 of the 2008 Act is similarly structured. One of the criticisms of the enforcement measures under the 1973 Act was that they did not effectively deter transgressors and were defective. ${ }^{126}$ In terms of section $440 \mathrm{M}$ of the $1973 \mathrm{Act}$, the SRP could approach the court for enforcement of the SRP Code. Further, in terms of section 440M(4) of the 1973 Act, any person who suffered damages could claim such damages from any person who caused such damages. However, these were regarded inadequate and hence the 2008 Act made significant changes. ${ }^{127}$ Due to the concerns raised about the efficacy of the enforcement measures in the 1973 Act,

120 See General Principles of the UK City Code.

121 The principles are also followed in the European Union as required by the EU Takeover Directive. Some of the principles are also applied in Australia. See section 602 of the Australian Corporations Act 2001 dealing with the Eggleston Principles. Some of the principles are similar to the general principles in the UK City Code.

Harald Baum, Takeover Law in the EU and Germany: Comparative Analysis of a Regulatory Model, 3 University of Tokyo Journal of Law and Politics 60 (2006). See DTI Guidelines, at 43. The enforcement measures under the 1973 Act were contained in sections 440 L and 440M.

See DTI Guidelines, at 46.

See Id. at 42 . 
the 2008 Act effected a number of changes and additional remedies. In terms of section 119(4) of the Act, the TRP may request filing of documents for approval; receive complaints; conduct investigations; and issue compliance notices in cases on non-compliance. In addition, section 119(5) provides that in order to ensure compliance, the TRP where required, may: prohibit or require any action by a person; or order a person to divest of an acquired asset; or account for profits. Section 440M of the 2008 Act had similar requirements, but the difference is that the TRP may also issue a compliance notice before approaching the courts. ${ }^{128}$ Section 121 also specifically provides that parties must not enter into such transaction unless they do so in accordance with the general requirements of the Act and TRP regulations. The compliance notice is similar to the compliance rulings that may be issued by the United Kingdom Panel on Takeovers and Mergers in section 10(d) of the United Kingdom City Code. ${ }^{129}$ The enforcement provisions of the 2008 Act are set out in Chapter 7, as read with the regulations in Chapter 7 of the Companies Regulations 2011 These provisions provide detailed steps and procedures in order to enforce compliance with the Act and the regulations. In terms of section 168 , any person may lodge a complaint with the TRP. The TRP in its discretion, may refer the matter to the Companies Tribunal in cases where it believes that the matter falls within that body's powers; ${ }_{i}^{130}$ may refer the matter to another entity for resolution; ${ }^{131}$ may appoint an inspector or investigator to investigate the complaint. ${ }^{132}$ On conclusion of the investigation, TRP may among others, excuse the person against whom a complaint has been raised; ${ }^{133}$ refer the matter to the National Prosecuting Authority ${ }^{134}$ or other authority when it believes that an offence has been committed; ${ }^{135}$ issue a notice of non-referral to the complainant; ${ }_{i}^{136}$ initiate legal proceedings in the name of the complainant in appropriate cases ${ }_{1}^{137}$ or issue a compliance notice. ${ }^{138}$ The TRP may also publish the result on any investigation. ${ }^{139}$ Where a matter has been referred by the TRP

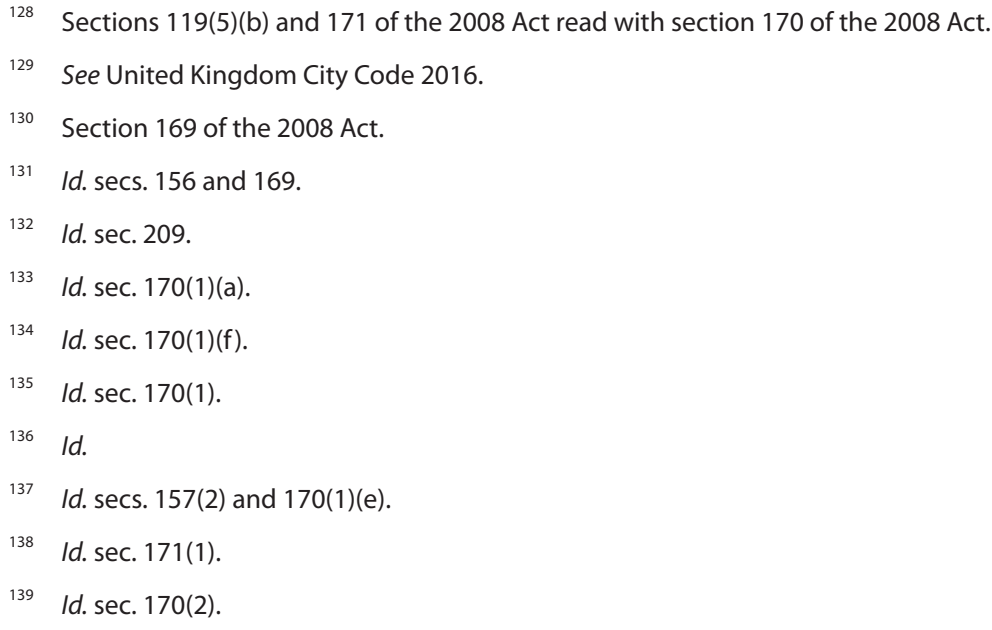

Sections 119(5)(b) and 171 of the 2008 Act read with section 170 of the 2008 Act. 
to the Takeover Special Committee for its decision or hearing, the Takeover Special Committee may issue a compliance notice in terms of section 171. Such a compliance notice may require a person to restore the assets to a company or to any other person, or cease or correct or reverse any action that resulted in contravention of the Act. A person who has been issued with such a notice may object in terms of section 172 and follow a procedure set out therein, including making representations. ${ }^{140}$ In terms of section 172(4), a decision by the Takeover Special Committee is binding subject to a right of review or appeal to a court.

The compliance notice issued by the TRP remains in force until it has been set aside by the Takeover Special Committee, if it was issued by the Executive Director, and in the case of a compliance notice issued by the Takeover Special Committee, until it has been set aside by a court. ${ }^{141}$ The Executive Director may issue a compliance certificate once compliance has been achieved. ${ }^{142}$ When a compliance notice is issued to a person, a copy of such a notice must also be sent to the licensing authority that granted the license authorising that person to conduct business. ${ }^{143}$ It appears that this provision is intended to ensure that licensing authorities are aware of the conduct of licensees. This provision may deter would-be transgressors from contravening the Act as it may have a negative effect on the conditions of their license. In terms of section 171(7), failure to comply with a compliance notice issued may result in a person being fined up to 10 percent of annual turnover by a court on application by the TRP. Non-compliance may also be referred to the National Prosecuting Authority for prosecution as an offence. In addition, to offences which specifically relate to failure to comply with mergers and acquisitions provisions, a number of sections are aimed at ensuring that the TRP is able to perform its functions and investigate transgressions without being obstructed by other parties. Offences are created in terms of a number of sections to assist in compliance. These sections include; section 213 relating to breach of confidence, section 214 dealing with the making of false statements, reckless conduct and non-compliance, and section 215 relating to any actions intended to hinder the TRP in administering the Act. Commission of such offences may result in a prosecution and on conviction by a court; such a person may be imprisoned for a period of 12 months in respect of convictions for offences in terms of any other sections. However, the period of imprisonment for convictions for any offences in terms of sections 213 and 214 is 10 years or a fine or both. It is suggested that the legislature considers these offences to be serious; hence the penalties. However, a person may not be subject to both an administrative fine and an imprisonment. ${ }^{144}$

\footnotetext{
140 Sections $172(1)$ and 172(2) of the 2008 Act.

141 Id. sec. 171(5).

142 Id. sec. 171(6).

143 Id. sec. 171(3)

144 Id. sec. $171(7)$
} 
In terms of section 218 of the Act, a person may have a civil action against any person for loss or damage suffered, as a result of any contravention by such a person of any provision of the new Act. This section is similar to section 440M(4) of the 1973 Act, in terms of which persons who suffered damages could claim damages against the person who caused them such damages. The TRP may also apply to the court to declare a director to be a delinquent or under probation in certain circumstances, ${ }^{145}$ for instance where the director has been acting as a director contrary to the provisions of section 69 , due to the disqualifications in that section, or has abused his position as director. ${ }^{146}$

Finally, in order to assist and strengthen investigation into alleged noncompliance with the provisions of the new Act, section 159(4) offers whistle-blowers protection from any civil or criminal liability for disclosures made subject to certain safeguards.

In terms of section 119(6), the TRP may also wholly or partially exempt application of any affected transaction or offer from application of Part B, Part C of Chapter 5 of the Act and the Takeover Regulations where there is no reasonable potential for prejudicing the interests of any party to the transaction, ${ }^{147}$ the cost of enforcing compliance will be disproportionate to the transaction ${ }^{148}$ or where exemption is reasonable and justifiable in the circumstances, taking into consideration the principles and purposes of the TRP regulations. ${ }^{149}$ This exemption is similar to that provided in terms of Rule 34 of the old SRP Code that was thought to provide broader grounds for exemption. ${ }^{150}$ However, it appears that the ability of the TRP to grant exemptions in terms of this section is circumscribed due to the factors, which the TRP must consider in granting the exemption in the section. It has been suggested that section 119(6)(c) could be interpreted in such a way that it affords broad grounds for exemption, provided that the tests of reasonableness and justice can be met..$^{151}$ Finally, in terms section 6 , the TRP may apply to a court to:

declare any agreement, transaction, arrangement, resolution or any provision of a company's Memorandum of Incorporation or rules-

\footnotetext{
145 Section $162(3)$ of the 2008 Act.

146 Id. sec. 162(5).

147 Id. sec. 119(6)(a).

148 Id. sec. 119(6)(b).

149 Id. sec. $119(6)(c)$

150 See rule 34 of the SRP Code, which provided in general terms that the Panel shall enjoy a general discretion to authorise, subject to such terms and conditions as it may prescribe, non-compliance with or departure from any requirement of the Code and to excuse or exonerate any party from failure to comply with any such requirement.

151 See section $119(6)(c)$ of the 2008 Act.
} 
(a) to be primarily or substantially intended to defeat or reduce the effect of a prohibition or requirement established by or in terms of an unalterable provision of this Act; and

(b) void to the extent that it defeats or reduces the effect of a prohibition or requirement established by or in terms of an unalterable provision of this Act.

\section{A Brief Overview of Some of the Disclosure Regulations for Mergers and Acquisitions}

The Minister in consultation with the chairperson of the TRP may prescribe regulations in respect of affected transactions by notice in the Government Gazette..$^{152}$ This is similar to the 1973 Act where the SRP made rules and regulations that were then approved by the Minister and published in the Government Gazette. ${ }^{153}$ The JSE Limited Listings requirements also deal with rules on M\&As..$^{154}$ The promulgation of the 2008 Act resulted in the SRP Code being rewritten with a new name in the form of the Takeover Regulations instead of the SRP Code. ${ }^{155}$ The TRP regulations in the main have incorporated most of the SRP Code provisions. ${ }^{156}$ The TRP regulations also read more like formal regulations as compared to the SRP Code, which was drafted in a different style. The Takeover Regulations are found in Chapter 5 of the Companies Regulations 2011 (the Regulations). The regulations covers details on the practical procedures required to apply the $2008 \mathrm{Act}$, including general rules relating to negotiations, ${ }^{157}$ announcements required, ${ }^{158}$ duties and conduct of parties to affected transaction, ${ }^{159}$ and procedures of the TRP. ${ }^{160}$ The regulations also provides for the disclosures required during affected transactions and who is responsible for such disclosures. The regulations set out detailed requirements for disclosures in M\&A documents to be considered by the shareholders. Some of the documents must be filed with the TRP and be approved by the TRP prior to being sent to shareholders. ${ }^{161}$ The regulations among others provides for: time

\footnotetext{
152 Section 120 of the 2008 Act. 
period for publishing announcements about $M \& A s$ and the relevant document; and how and when announcements and documents must be sent to shareholders. The regulations also set out which document must be available for shareholders to inspect during the course of an affected transaction or offer. The documents include annual financial statements, documents evidencing any valuations of property, and memoranda of incorporations. ${ }^{162}$ It clear that practitioners structuring M\&As and drafting the relevant documents under the 2008 Act need to be careful as failure to do so may result non-compliance with the M\&A provisions. Under the 2008 Act, practitioners should consider the requirements of Act and those of the regulations. This is unlike the provisions of the 1973 Act where it was possible to comply with M\&A requirements, by mainly referring to the SRP Code. ${ }^{163}$ The 1973 Act in Chapter XVA merely provided a basis for regulating M\&As. While the SRP Code provided comprehensive underlying principles of regulating M\&As, it also had prohibitions, and the powers of the SRP in additions to those contained in the 1973 Act. $^{164}$

\section{Concluding Comments}

Mergers and acquisitions raise numerous conflicts between different parties. Shareholders would prefer to sell their shares to the highest bidder, or may not prefer to sell at all, and yet may be forced to so; directors and management may feel threatened that their positions will no longer exist due to cost cutting from the new controller; Employees are also concerned about the possible downsizing and retrenchments. Therefore, it is not possible for legislation to completely cater for all these competing interests. However, a balancing of interests is required if the legislature is to achieve its stated objectives. Accordingly, from a merger and acquisition regulatory approach, TRP is required to implement the M\&A provisions in line with the intention of the legislature to promote transparent, efficient and predictable company acquisitions and mergers as indicated in the preamble to the Act. The TRP is required to consider the objectives of the legislature when interpreting and applying the takeover provisions. The 2008 Act attempts to balance the conflicting interests of the various parties. A close scrutiny of the provisions shows that shareholder protection is provided in a number of ways. For example, minority shareholders are

162 Regulation 106 of the Companies Regulations 2011 requires certain documents to be available for inspection.

163 See the SRP Code. The SRP Code had detailed rules which contained all the general principles and the rule relating to prohibited conduct and disclosures. The fact that the 2008 Act separate obligations and detailed disclosures makes it imperative that both Chapter 5 of the 2008 Act and Chapter 5 of the Companies Regulations 2011 are consulted when undertaking M\&As, whereas with the SRP Code practitioners could rely on for compliance the rules in the SRP Code with limited reference to Chapter XVA of the 1973 Act. 
provided with protection by means of disclosures, appraisal rights and voting, among others. But, minority shareholders are also precluded from imposing their will on the majority ${ }^{165}$ For example, the will of the majority will be carried through when a fundamental transaction has been approved in accordance with the requirements of the Act. ${ }^{166}$ Another example is that an acquirer may squeeze out the remaining minority shareholders where a majority of 90 percent have accepted its offer. ${ }^{167}$ Finally, a dissenting shareholder may have no further rights once they send a demand to be paid a fair value for their shares in cases of appraisal rights. ${ }^{168}$

In promoting efficient regulation of $M \& A s$, the legislature preferred specialised regulatory body such as the TRP in continuing to regulate M\&As. In line with the objectives of the legislature, the TRP can ensure a speedy and effective enforcement. Simple and efficient enforcement measures are required because in some cases, noncompliance may be so minor that there is no need to approach the courts. In that situation, it is preferable that an administrative tribunal such as the TRP and Takeover Special Committee intervene for quicker in speedy resolution. This also avoids clogging the general public court system with private minor shareholder issues. Specialised tribunals are appropriate to resolves such matters as they are better qualified to handle such matters. Shareholder approval of fundamental transactions, appraisal rights and the relevant disclosures are some of the important protection for shareholders in terms of the 2008 Act. Shareholders are also entitled to court review in certain circumstances. The legislature has in the most retained the provisions of the 1973 Act in respect of regulating mergers and acquisitions, while at the same time effecting some improvements and additions. The M\&A provisions seem to be in line with what was intended in the DTI Guidelines despite some problematic interpretations. The recently published proposed amendments in the Companies Amendment Bill will go a long way in resolving some of the interpretation and application problems of the 2008 Act. However, some of the regulations and provisions of the Act need to be improved, others need an amendment, for better interpretation and application. ${ }^{169} \mathrm{In}$ general, the regulations have been well received and are workable. ${ }^{170}$ Further, scholars and practitioners have welcomed the new M\&As provisions, and regard the provisions as an improvement on those of the 1973 Act.

165 See Davids et al. 2010, at 337-338.

166 See section 115 of the 2008 Act, dealing with voting approvals for fundamental transaction.

167 See section 124 of the 2008 Act, dealing with expropriations and squeeze outs.

168 See Id. sec. 164(9).

169 See regulation 102 of the Companies Regulations 2011 dealing with timelines. It appears that the regulation may be in conflict with the JSE Listings requirements in certain respects. It would be preferred if the timelines could be aligned with those of the JSE Listings requirements for efficiency.

170 See Latsky 2014, at 362 \& 384. 
In promulgating the merger and acquisitions in the 2008 Act, the legislature sought to ensure that South African company law is updated and be aligned with developments internationally, and also, considers the South African changing business landscape as a developing economy. ${ }^{171}$ Increasing globalisation may lead to more cross border mergers and acquisitions as companies seek new markets for their products and, investors seek better returns for their capital. The simplified, clearer and efficient merger and acquisition provisions may encourage increased mergers and takeovers activity due to inward investment into South Africa when investors and market participants gain confidence in the South African corporate law. Based on the analysis of the M\&A provisions in the 2008 Act, it is concluded that the South African merger and acquisition provisions are compatible with the other takeover regimes in other countries, despite some deficiencies.

\section{References}

Baum H. Takeover Law in the EU and Germany: Comparative Analysis of a Regulatory Model, 3 University of Tokyo Journal of Law and Politics 60 (2006).

Boardman N. A Critical Analysis of the New South African Takeover Laws as Proposed Under the Companies Act 71 of 2008, Acta Juridica 306 (2010).

Cassim M.F. The Introduction of the Statutory Merger in South African Corporate Law: Majority Rule Offset by the Appraisal Right (Part 2), 20 South African Mercantile Law Journal 147 (2008).

Wainer H.E. The New Companies Act: Peculiarities and Anomalies, 126(4) South African Law Journal 806 (2009).

\section{Information about the author}

Madimetja Phakeng (Cape Town, South Africa) - The Cape Bar - Society of Advocates (40 Queen Victoria St., Cape Town City Centre, Cape Town, 8000, South Africa; e-mail: madimetjaphakeng@yahoo.com).

171 DTI Guidelines, at 4. 